\title{
Pengaruh Kepemilikan Institusional, Konsentrasi Kepemilikan dan Dividen Terhadap Kinerja Perusahaan
}

\author{
Ira Wikartika, Fajar Syaiful Akbar \\ Fakultas Ekonomi dan Bisnis, Universitas Pembangunan Nasional "Veteran" Jawa Timur
}

Improving company performance is crucial for the company's future life continuity. The company has a primary objective that increases the prosperity of shareholders. Basically, investors expect returns in the form of dividends. The structure of ownership and dividends is one way to improve the company's performance. This research aims to determine the influence of institutional ownership, ownership concentration, and dividends on the company's performance. The research methods used are quantitative methods using multiple linear regression analysis techniques. The research population uses companies listed on LQ45 in the Indonesia Stock Exchange. Sample research of 45 companies during the year 2018. The results showed that institutional ownership and ownership concentration did not affect the company's performance while dividends were influential in the company's performance.

OPEN ACCESS ISSN 2528-4649 (online) ISSN 2338-4409 (print)

${ }^{\star}$ Correspondence:

Received: 2 September 2019 Accepted: 25 Februari 2020 Published: 4 Maret 2020

Citation:

Wikartika I and Syaiful Akbar F (2020) Pengaruh Kepemilikan Institusional, Konsentrasi Kepemilikan dan Dividen Terhadap

Kinerja Perusahaan.

Pengaruh Kepemilikan Institusional,

Konsentrasi Kepemilikan dan

Dividen Terhadap Kinerja

Perusahaan. 6:1.

doi: http://doi.org/10.21070/jbmp.v

$6 i 1.444$
Peningkatan kinerja perusahaan sangat penting bagi keberlangsungan hidup perusahaan di masa mendatang. Perusahaan mempunyai tujuan utama yaitu meningkatkan kemakmuran pemegang saham. Pada dasarnya investor mengharapkan return dalam bentuk dividen. Struktur kepemilikan dan dividen merupakan salah satu cara untuk meningkatkan kinerja perusahaan. Penelitian ini bertujuan untuk mengetahui pengaruh kepemilikan institusional, konsentrasi kepemilikan, dan dividen terhadap kinerja perusahaan. Metode penelitian yang digunakan yaitu metode kuantitatif dengan menggunakan teknik analisis regresi linier berganda. Populasi penelitian menggunakan perusahaan yang terdaftar dalam LQ45 di Bursa Efek Indonesia. Sampel penelitian sebanyak 45 perusahaan pada tahun 2018 Hasil penelitian menunjukkan bahwa kepemilikan institusional dan konsentrasi kepemilikan tidak berpengaruh terhadap kinerja perusahaan sedangkan dividen berpengaruh terhadap kinerja perusahaan.

\section{PENDAHULUAN}

Dasar pemikiran penelitian ini terkait dengan teori agensi yang dikemukakan oleh Jensen \& Meckling pada tahun 1976. Teori keagenan (agency theory) menyatakan bahwa hubungan agensi muncul ketika satu orang atau lebih (principal) mempekerjakan orang lain (agent) untuk memberikan suatu jasa dan kemudian mendelegasikan wewenang pengambilan keputusan kepada agent tersebut. Dalam teori keagenan, pemegang saham (principal) sebagai pihak yang memiliki saham sepenuhnya meminta manajemen (agent) untuk memaksimalkan return 
bagi mereka. Masalah keagenan terjadi ketika tujuan dari principal dan agent bertentangan. Permasalahan agensi dalam hubungan antara pemilik modal dengan manajer adalah bagaimana sulitnya pemilik dalam memastikan bahwa dana yang ditanamkan tidak diambil alih atau diinvestasikan pada proyek yang tidak menguntungkan sehingga tidak mendatangkan return.

Tujuan utama perusahaan adalah meningkatkan nilai perusahaan melalui peningkatan kemakmuran para pemegang saham (Brigham dan Gapenski, 1999). Pada umumnya para investor mempunyai tujuan utama untuk meningkatkan kesejahteraannya yaitu dengan mengharapkan return dalam bentuk dividend maupun capital gain. Investor yang tidak bersedia berspekulasi mempunyai pandangan bahwa dividend yang diterima pada saat ini akan mempunyai nilai yang lebih tinggi daripada capital gain yang akan diterima di masa mendatang, inilah alasan mereka lebih menyukai dividend daripada capital gain. Dividen yang dibayarkan kepada para pemegang saham tergantung kepada kebijakan masing-masing perusahaan, sehingga memerlukan pertimbangan yang serius dari pihak manajemen perusahaan. Kebijakan dividen dipandang sangat penting karena menentukan bagaimana dan berapa proporsi laba yang akan dibagikan kepada pemegang saham dan yang akan ditahan untuk diinvestasikan kembali. Kebijakan tersebut melibatkan dua pihak yaitu pemegang saham dan manajemen perusahaan yang dapat mempunyai kepentingan yang berbeda. Penyatuan kepentingan dari kedua pihak tersebut seringkali menimbulkan masakah yang sering disebut dengan masalah keagenan. Myron Gordon (1963) dan John Litner (1962), menyatakan bahwa nilai perusahaan akan dimaksimalkan oleh rasio pembagian dividen yang tinggi, karena investor menganggap bahwa dividen aktual lebih kecil risikonya dibanding risiko kenaikan nilai modal.

Struktur kepemilikan menggambarkan persebaran pemegang saham yang diproksikan dalam bentuk persentase. Konsentrasi kepemilikan mencerminkan pemisahan antara pemegang saham mayoritas dan minoritas. Pemegang saham mayoritas cenderung bertindak untuk kepentingannya sendiri dengan mengorbankan pemegang saham minoritas sehingga berpengaruh pada kinerja perusahaan. Konsentrasi kepemilikan pada negara yang memiliki hukum dan peraturan yang lemah dalam melindungi pemegang saham minoritas, situasi pemegang saham mayoritas akan tercipta mengakibatkan kinerja perusahaan menurun (Khamis, 2015). Jensen \& Meckling (1976) menjelaskan adanya pemisahan antara kepemilikan dengan pengendali perusahaan akan menimbulkan konflik antara keduanya. Kepemilikan institusional merupakan salah satu upaya dalam menanggulangi konflik agen yang terjadi. Kepemilikan institusional memiliki kemampuan yang besar dalam melakukan pengawasan untuk melindungi investasinya sehingga mempengaruhi manajemen secara signifikan sehingga kinerja perusahaan akan meningkat (Al-Najjar, 2015). Manajemen akan bertindak sesuai dengan tujuan perusahaan dengan meningkatkan kinerja mereka yang diwujudkan dengan meningkatnya kinerja perusahaan.

Penilaian kinerja perusahaan dikelompokkan menjadi dua yaitu penilaian kinerja nonkeuangan dan penilaian kinerja keuangan. Penilaian kinerja perusahaan dengan menggunakan ukuran keuangan lebih sering digunakan karena terdapat standar perbandingan yang potensial, baik berupa laporan keuangan di masa lalu atau dengan laporan keuangan perusahaan lain yang sejenis. Kinerja keuangan merupakan hasil yang didapat dari aktivitas operasi perusahaan. Setiap perusahaan menginginkan kinerja perusahaan selalu meningkat dari tahun ke tahun. Kinerja keuangan dapat digambarkan oleh model Tobin's Q. Tobin's Q dikembangkan oleh Prof. James Tobin pada tahun 1967. Tobin's Q merupakan ukuran mengenai efektifitas manajemen dalam memberdayakan sumber-sumber daya ekonomis dalam kekuasaannya. Pengukurannya adalah apabila nilai tobin's $Q$ lebih dari satu berarti investasi harta yang dimiliki perusahaan dapat memperoleh laba, sehingga akan membuat rangsangan untuk investasi baru, namun apabila nilainya kurang dari satu berarti melakukan investasi dalam aktiva perusahaan kurang menarik.

Brigham dan Gapenski mengatakan bahwa kebijakan dividen adalah keputusan atas pembagian earning after tax (EAT) yang dibagikan sebagai dividen dan laba yang ditahan yang akan menjadi sumber internal perusahaan. Perusahaaan yang memutuskan untuk membagikan dividen secara otomatis akan berdampak terhadap laba ditahan yang menjadi berkurang yang artinya sumber dana internal yang digunakan sebagai pengembangan perusahaan menjadi berkurang, namu dengan membagikan dividen perusahaan dapat mengurangi agency cost 
dikarenakan mengurangi total arus kas perusahaan dimana biasanya pihak manajemen tidak memperhitungkan dalam menggunakan kas tersebut. Teori kebijakan dividen :

- Dividend Irrelevance Theory

Teori ini dikemukakan oleh Merton Miller dan Franco Modigliani (Brigham dan Houston, 2006) menyatakan bahwa kebijakan dividen tidak memiliki pengaruh terhadap harga saham dan biaya modal perusahaan sehingga dikatakan tidak relevan, yang pada kenyatannya terkait dengan tidak adanya pajak dan biaya transaksi. Nilai perusahaan lebih ditentukan oleh kemampuan manajemen dalam mengelola perusahaan untuk memperoleh laba, bukan pada bagaimana laba tersebut dibagikan dalam bentuk dividen dan laba ditahan.

- Bird in The Hand Theory

Teori ini dikemukakan oleh Gordon dan Lintner (Brigham dan Houston, 2006) menyatakan bahwa imbal hasil investasi turun seiring dengan peningkatan pembayaran dividen karena investor menilai bahwa imbal hasil yang didapatkan dari dividen lebih pasti dibandingkan imbal hasil dari investasi. Investor lebih menyukai dividen saat ini dibandingkan menunggu capital gain di masa mendatang sehingga risiko dividen lebih rendah daripada capital gain.

\section{METODE PEN}

Populasi merupakan seluruh kumpulan elemen yang menunjukkan ciri-ciri tertentu yang dapat digunakan untuk membuat kesimpulan (Sanusi, 2011). Populasi penelitian yang digunakan adalah perusahaan di BEI yang terdaftar dalam LQ45 pada tahun 2018. Pengambilan sampel dilakukan dengan menggunakan teknik random sampling, yaitu dengan cara pengambilan sampel yang semua anggota populasi diberikan kesempatan untuk dipilih menjadi sampel. Metode pengambilan sampling adalah metode sampling jenuh. Sampel penelitian sebanyak 45 perusahaan dengan menggunakan sebanyak 135 unit analisis.

Metode analisis dalam penelitian ini menggunakan model analisis regresi berganda ( $m u l-$ tiple regression) dengan metode Ordinary Least Square. Persamaan regresi akan menjelaskan bagaimana bentuk pengaruh setiap variabel independen terhadap variabel dependen. Adapun persamaan regresinya adalah sebagai berikut :

Tobin's $\mathrm{Q}=\alpha+\beta 1 \mathrm{IO}+\beta 2 \mathrm{CO}+\beta 3 \mathrm{Div}+\varepsilon_{i t}$

Keterangan :

Tobin's Q = Kinerja Perusahaan

$\mathrm{IO}=$ Kepemilikan Institusional

$\mathrm{CO}=$ Konsentrasi Kepemilikan

Div $=$ Dividen

$\varepsilon_{i t}=$ Standar error

\section{HASIL DAN PEMBAHASAN}

\section{Multikolinieritas}

Multikolinearitas merupakan uji yang dilakukan untuk memastikan apakah di dalam sebuah model regresi ada interkorelasi atau kolinearitas antar variabel bebas. Interkorelasi adalah hubungan yang linear atau hubungan yang kuat antara satu variabel bebas atau variabel prediktor dengan variabel prediktor lainnya di dalam sebuah model regresi. Interkorelasi itu dapat dilihat dengan nilai koefisien korelasi antara variabel bebas, nilai VIF dan nilai tolerance.

Dalam pengujian asumsi klasik terhadap analisis regresi linier berganda ini menyatakan bahwa hasil analisis penelitian ini menunjukkan tidak adanya gejala multikolinieritas pada semua variabel bebas dimana nilai VIF pada semua variabel (lebih kecil dari 10) dan atau nilai tolerance lebih dari 0,01 . 
TABLE 1 | Uji Multikolinieritas

\begin{tabular}{|c|c|c|c|c|c|c|c|}
\hline \multicolumn{8}{|c|}{ Coefficientsa } \\
\hline \multirow{2}{*}{\multicolumn{2}{|c|}{ Model }} & \multicolumn{2}{|c|}{ Unstandardized Coefficients } & $\begin{array}{l}\text { Standardized } \\
\text { Coefficients }\end{array}$ & $\mathrm{t}$ & Sig. & $\begin{array}{l}\mathrm{Cc} \\
\text { tic }\end{array}$ \\
\hline & & & Std. Error & Beta & & & To \\
\hline \multirow{4}{*}{1} & (Constant) & 1273125.873 & 1362211.457 & & .935 & .357 & \\
\hline & Kepk.Ins. & 16725.177 & 28149.757 & .129 & .594 & .556 & .5 \\
\hline & Kons.Kepk. & -25882.762 & 20229.111 & -.266 & $\begin{array}{l}- \\
1.279\end{array}$ & .209 & \\
\hline & Dividen & 3726.504 & 1853.546 & .345 & 2.010 & .052 & .81 \\
\hline
\end{tabular}

\section{Heteroskedastisitas}

Heteroskedastisitas merupakan varian dari residual dari satu pengamatan ke pengamatan lain mempunyai varian yang berbeda. Model regresi yang baik tidak mempunyai heteroskedastisitas. Pengujian heteroskedastisitas di sini menggunakan korelasi rank Spearman antara residual dengan seluruh variabel bebas.

TABLE 2

\begin{tabular}{|c|c|c|c|c|}
\hline \multicolumn{5}{|l|}{ Correlations } \\
\hline \multirow{4}{*}{$\begin{array}{l}\text { Correlation Coefficient } \\
\text { Kepk. Bis. (2-tailed) }\end{array}$} & Kepk.Ins. & Kons.Kepk & Dividen & Unstandardized Residual \\
\hline & 1.000 & $.663^{\star \star}$ & -.178 & .111 \\
\hline & . & .000 & .285 & .157 \\
\hline & 38 & 38 & 38 & 38 \\
\hline Correlation Coefficient & $.663^{\star \star}$ & 1.000 & .045 & .234 \\
\hline Kons. Steapl(2-tailed) & .000 & . & .789 & .158 \\
\hline Spearman's & 38 & 38 & 38 & 38 \\
\hline rho Correlation Coefficient & -.178 & .045 & 1.000 & -.196 \\
\hline \multirow[t]{2}{*}{ Dividesig. (2-tailed) } & .285 & .789 & . & .239 \\
\hline & 38 & 38 & 38 & 38 \\
\hline \multirow{3}{*}{$\begin{array}{l}\text { Correlation Coefficient } \\
\text { Unstandardized } \\
\text { Residual. }(2 \text {-tailed) }\end{array}$} & .111 & .234 & -.196 & 1.000 \\
\hline & .157 & .158 & .239 & . \\
\hline & 38 & 38 & 38 & 38 \\
\hline
\end{tabular}

Hasil analisis menunjukkan bahwa nilai korelasi antara variabel bebas dengan residual yaitu pada variabel kepemilikan institusional dan konsentrasi kepemilikan memiliki nilai signifikansi lebih besar dari 0,05 artinya semua variabel bebas tersebut tidak mempunyai korelasi yang signifikan dengan residual (nilai signifikansi lebih besar dari 0,10) maka hasil analisis ini dapat disimpulkan model regresi tidak terjadi heteroskedastisitas.

\section{Autokorelasi}

Autokorelasi merupakan korelasi antara kesalahan pengganggu pada periode $t$ dengan kesalahan pengganggu periode t-1 (sebelumnya). Uji durbin watson akan menghasilkan nilai Durbin Watson (DW) yang nantinya akan dibandingkan dengan 2 nilai durbin watson tabel, yaitu Durbin Upper (DU) dan Durbin Lower (DL).

TABLE 3 | Hasil Uji Autokorelasi

\begin{tabular}{|c|c|c|c|c|c|}
\hline \multicolumn{6}{|c|}{ Model Summaryb } \\
\hline Model & $\mathrm{R}$ & R Square & Adjusted R Square & Std. Error of the Estimate & Durbin-Watson \\
\hline 1 & $.370 \mathrm{a}$ & .137 & .060 & 1559713.236 & 1.835 \\
\hline
\end{tabular}

Asumsi klasik yang mendeteksi adanya autokorelasi dilihat dari hasil analisis yang menunjukkan hasil bahwa nilai Durbin Watson sebesar 1.835. Nilai durbin watson tabel dengan jum- 
lah data $(\mathrm{N})=37$ dan jumlah variabel bebas $(\mathrm{K})=3$ dan $\alpha=0,05$ adalah $\mathrm{DL}=1,3635$ dan DU $=1,5904$ dan nilai 4 -du $=4-1,5904=2,4096$. Apabila $\mathrm{d}=1,915>\mathrm{dU}=1,5904$ maka tidak terdapat autokorelasi positif. Nilai $(4-\mathrm{du})=2,4096>\mathrm{dU}=1,5904$ maka tidak terdapat autokorelasi negatif. Dengan demikian terletak pada daerah keragu-raguan dan secara keseluruhan pada model regresi ini tidak terjadi autokorelasi.

\section{Koefisien Determinasi dan Kesesuaian Model}

Koefisien determinasi $\left(\mathrm{R}^{2}\right)=0,167$ Artinya, dividen dipengaruhi oleh variabel independen (kepemilikan institusional dan konsentrasi kepemilikan) sebesar 16,7 persen sedang sisanya sebesar 83,3 persen dipengaruhi oleh variabel lain selain kedua variabel independen dalam model tersebut.

TABLE 4 | Uji F Test

\begin{tabular}{|c|c|c|c|c|c|c|}
\hline \multicolumn{7}{|c|}{ ANOVAb } \\
\hline \multicolumn{2}{|c|}{ Model } & Sum of Squares & df & Mean Square & $\mathrm{F}$ & Sig. \\
\hline & Regression & 1.308E13 & 3 & 4.360E12 & 1.792 & $.167 a$ \\
\hline \multirow[t]{2}{*}{1} & Residual & 8.271E13 & 34 & 2.433E12 & & \\
\hline & Total & $9.579 \mathrm{E} 13$ & 37 & & & \\
\hline
\end{tabular}

Hasil pengujian dengan $\mathrm{F}$ test menunjukkan bahwa nilai signifikansi $=0,167$ lebih besar dari 0,10 yang berarti tidak signifikan, sehingga penggunaan model regresi dalam penelitian ini kurang sesuai.

\section{Regresi Linier Berganda}

\begin{tabular}{|c|c|c|c|c|c|c|c|}
\hline \multicolumn{8}{|c|}{ Coefficientsa } \\
\hline \multirow{2}{*}{\multicolumn{2}{|c|}{ Model }} & \multicolumn{2}{|c|}{ Unstandardized Coefficients } & $\begin{array}{l}\text { Standardized } \\
\text { Coefficients }\end{array}$ & $\mathrm{t}$ & Sig. & \\
\hline & & & Std. Error & Beta & & & To \\
\hline \multirow{4}{*}{1} & (Constant) & 1273125.873 & 1362211.457 & & .935 & .357 & \\
\hline & Kepk.Ins. & 16725.177 & 28149.757 & .129 & .594 & .556 & .5 \\
\hline & Kons.Kepk. & -25882.762 & 20229.111 & -.266 & $\begin{array}{l}- \\
1.279\end{array}$ & .209 & .5 \\
\hline & Dividen & 3726.504 & 1853.546 & .345 & 2.010 & .052 & .8 \\
\hline
\end{tabular}

Hasil persamaan regresi linier berganda :

Tobin's $\mathrm{Q}=16.725,2 \mathrm{IO}-25.882,8 \mathrm{CO}+3.726,5 \mathrm{Div}+\mathrm{ei}$

\section{Pengaruh kepemilikan institusional terhadap kinerja perusahaan}

Hasil analisis menunjukkan bahwa variabel kepemilikan institusional memiliki nilai signifikansi sebesar 0,556 lebih besar dari 0,10. Ini berarti kepemilikan institusional tidak berpengaruh terhadap kinerja perusahaan. Hal ini menunjukkan bahwa perusahaan senantiasa meningkatkan kemakmuran pemegang saham dengan memberikan perhatian bagi semua para pemegang saham dan tidak membedakan jenis kepemilikannya baik institusi maupun individu. Hasil penelitian ini mendukung penelitian Al-Najjar (2015) yang menunjukkan bahwa kepemilikan institusional tidak mempengaruhi kinerja perusahaan. 


\section{Pengaruh konsentrasi kepemilikan terhadap kinerja perusahaan}

Hasil analisis menunjukkan bahwa variabel konsentrasi kepemilikan memiliki nilai signifikansi sebesar 0,209 lebih besar dari 0,10. Ini berarti konsentrasi kepemilikan tidak berpengaruh terhadap kinerja perusahaan. Hal ini menunjukkan bahwa perusahaan bertujuan untuk melindungi investasi bagi semua pemegang sahamnya baik pemegang mayoritas maupun pemegang minoritas. Hasil penelitian ini mendukung penelitian Fazlzadeth (2011) yang menunjukkan bahwa konsentrasi kepemilikan tidak mempengaruhi kinerja perusahaan.

\section{Pengaruh dividen terhadap kinerja perusahaan}

Hasil analisis menunjukkan bahwa variabel dividen memiliki nilai signifikansi sebesar 0,052 lebih kecil dari 0,10. Ini berarti dividen berpengaruh terhadap kinerja perusahaan. Hal ini menunjukkan bahwa perusahaan yang memiliki dividen tinggi lebih menyukai pendanaan dengan modal sendiri, sehingga akan meningkatkan kinerja keuangan perusahaan itu sendiri. Pembayaran dividen kepada pemegang saham akan mengurangi sumber-sumber dana yang dikendalikan oleh manajer, sehingga mengurangi kekuasaan manajer dan membuat pembayaran dividen mirip monitoring capital market yang terjadi apabila perusahaan memperoleh modal baru. Hasil penelitian ini mendukung penelitian Rizqia et. al. (2013) dan Kurnia (2017) yang juga menunjukkan bahwa dividen mempengaruhi kinerja perusahaan.

\section{KESIMPULAN}

\section{KESIMPULAN}

Kepemilikan institusional dan konsentrasi kepemilikan tidak berpengaruh terhadap kinerja perusahaan. Hal ini menunjukkan bahwa kinerja perusahaan tidak terpengaruh pada besar kecilnya proporsi kepemilikan institusional dan konsentrasi kepemilikan, disebabkan perusahaan senantiasa berupaya untuk dapat melindungi investasi dengan cara memberikan perhatian bagi semua para pemegang saham, tidak membedakan pemegang saham mayoritas dan minoritas. Dividen berpengaruh terhadap kinerja perusahaan. Hal ini menunjukkan bahwa perusahaan yang memiliki dividen tinggi lebih menyukai pendanaan dengan modal sendiri, sehingga akan meningkatkan kinerja perusahaan itu sendiri. Pembayaran dividen kepada pemegang saham juga dapat mengurangi sumber-sumber dana yang dikendalikan oleh manajer, sehingga mengurangi kekuasaan manajer dan membuat pembayaran dividen mirip monitoring capital market yang terjadi jika perusahaan memperoleh modal baru.

\section{APPENDIX}

1. Algifari. 2015. Analisis Regresi untuk Bisnis dan Ekonomi. Yogyakarta : BPFE.

2. Al-Najjar, Dana. 2015. The Effecf of Institusional Ownership on Firm Performance: Evidence from Jordanian Listed Firms. International Journal of Economics and Finance. 7 (12) : 97-105.

3. Berle, A. and Means, G. 1932. The Modern Corporation and Private Property. New York: Larcourt, Brace and World Inc., (Republished:1968)

4. Cooper. D.R. and Schindler, P.S. 2014. Business Research Methods. New York: McGraw-Hill.

5. Fauzi, Fitriya. and Stuart Locke. 2012. Board Structure. Ownership Structure and Firm Performance : A study of New Zealand listed-firms. Asian Academy of Management Journal of Accounting and Finance (AAMJAF). 8(2) : 43-67.

6. Fazlzadeth, Alireza. Ali Tahbaz Hendi and Kazem Mahboubi. 2011. The Examination of The Affect of Ownership Structure on Firm Performance in Listed Firm of Tehran Stock Exchange Based on The Type of The Indutry. International Journal of Business and Management. 6 (3): 249-266.

7. Gordon, M.J. 1963. Optimal Investment and Fiancing Policy. The Journal of Finance. 18 (2): 264-272. 
8. Jensen, M.C. and W.H. Meckling. 1976. Theory of The Firm : Manajerial Behaviour, Agency Cost, and Ownership Structure. Journal of Financial and Economics. 3 (4): 305-360.

9. Khamis, Reem. Allam Mohammed Hamdan and Wajeeh Elali. 2015. The Relationship between Ownership Structure Dimensions and Corporate Performance : Evidence from Bahrain. Australasian Accounting, Business and Finance Journal. 9 (4) : 38-56.

10. Kurnia, Denny. 2017. Analisis Signifikansi Leverage dan Kebijakan Dividen terhadap Nilai Perusahaan. Jurnal Akuntansi. 4(2) : 12-21.

11. Lintner, John. 1962. Dividends, Earnings, Leverage, Stock Prices and the Supply of Capital to Corporations. The Review of Economics and Statistics. 44 (3) : 243-269.

12. Rizqia, Dwita Ayu. Siti Aisjah dan Sumiati. 2013. Effect of Managerial Ownership, Financial Leverage, Profitability, Firm Size and Investment Opportunity on Dividend Policy and Firm Value. Research Journal of Finance and Accounting. 4 (11) : 120-130.

13. Sanusi, Anwar. 2011. Metode Penelitian Bisnis. Salemba Empat. Jakarta.

Conflict of Interest Statement: The authors declare that the research was conducted in the absence of any commercial or financial relationships that could be construed as a potential conflict of interest.

Copyright (C) 2020 Wikartika and Syaiful Akbar. This is an openaccess article distributed under the terms of the Creative Com- mons Attribution License (CC BY). The use, distribution or reproduction in other forums is permitted, provided the original author(s) and the copyright owner(s) are credited and that the original publication in this journal is cited, in accordance with accepted academic practice. No use, distribution or reproduction is permitted which does not comply with these terms. 